\title{
Analysis of Climate Migration in Niger: An Adaptation Strategy in Facing the Realities of the Context
}

\author{
Elhadji Idi ISSOUFOU ADAMOU ${ }^{1}$, Emrah AKBAŞ ${ }^{1}$ \\ Ankara Yildirim Beyazit University, Human and Social Sciences Faculty, \\ Department of Sociology, 06760 Ankara, Turkey \\ DOI: 10.31364/SCIRJ/v9.i05.2021.P0521857 \\ http://dx.doi.org/10.31364/SCIRJ/v9.i05.2021.P0521857
}

\begin{abstract}
This research aims to analyze climate migration as an adaptation strategy to the effects of climate change in the face of the realities of the context in Niger. Recurring climatic hazards degrade the natural resources (a strong link in the economy) necessary for the survival of the population. These climatic events amplify the socio-economic vulnerabilities of populations. This is why the development of adoption strategies at the national and local level are very necessary in order to make its impacts. This is why the development of adoption strategies at the national and local levels are very necessary in order to cope with climate change impacts. Indeed, in a context of rainfall deficit, degradation of agricultural and pastoral lands as well as other climatic manifestations, an agropastoral population $85 \%$ is forced to migrate in order to ensure its survival. This climate migration made in order to mobilize additional resources reduces the vulnerability of the population to the effects of climate change. The financial resources and social capital capitalized during this migratory experience allow the affected populations to emancipate themselves on a socio-economic level. Therefore, according to the results of this study, it was concluded that migration as the main strategy for adapting to the effects of climate change is a response and a very widespread practice in Niger.
\end{abstract}

Keywords: West Africa, Climate Change, Migration, Niger Context, Sociological Analysis.

\section{Introduction ${ }^{1}$}

Climate change is one of the most complex and worrying events of the 21 st century. It is a planetary social phenomenon which determines the fate of man and his environment. Therefore, it is more than necessary to question the relationship between the quality of the environment and human life. The disruption caused by climate change is a complex reality that currently leaves entire communities vulnerable.

In West Africa, and particularly in the Sahel, climate issues have raised more serious and legitimate concerns. In this region, droughts, floods, temperatures, torrential rains, winds are more violent and destructive than in the rest of the world. In addition, under the combined effects of climate change in the Sahel, agricultural and pastoral areas are degrading and losing their productivity. These recurring natural

\footnotetext{
${ }^{1}$ This article is developed and extended based on a Ph.D. thesis titled "Climate Change and Migration in West Africa: Sociological Analysis of the Niger Context" which will be presented soon.

Corresponding Author, Issoufou Adamou Elhadji Idi (Ph.D. candidate) in Sociology at Ankara Yildirim Beyazit University, Turkey, elhidi29issoufou@gmail.com, ORCID: 0000-0002-5224-8409
}

www.sciri.org

(C) 2021, Scientific Research Journal

http://dx.doi.org/10.31364/SCIRJ/v9.i05.2021.P0521857

This publication is licensed under Creative Commons Attribution CC BY. 
disasters degrade already limited natural resources. These natural resources, necessary for the survival of the population, form the strong link in the economy of the area.

Niger is characterized by high variability in climatic parameters, in particular rainfall, both spatially and temporally. This situation has recently caused recurrent rainfall deficits and repetitive droughts and famines. Thus, the country has experienced seven periods of drought over the past forty years and their consequences on agricultural and pastoral production, food security and socio-economic life have been very serious (PPCR, 2010; CNEDD, 2013).

Faced with all these situations, the populations find themselves obliged to create the conditions for an adaptation favorable to their survival. Developments in adoption strategies at the national and local levels have therefore become more than necessary in order to deal with the impacts of climate change. In Niger, among these strategies, migration occupies a prominent place. So in this country climate migration is one of the biggest strategies that offers prospects for adaptation to climate change. Indeed, in a context of rainfall deficit, degradation of agricultural and pastoral lands as well as other climatic manifestations, an agro-pastoral population $85 \%$ is forced to migrate in order to ensure its survival. This climate migration made in order to mobilize additional resources helps the population to cope with the effects of climate change. In fact, the financial resources and social capital capitalized during this migratory experience allow the affected populations to improve the conditions for their emancipation from a social and economic point of view.

\section{Literature review}

\section{Climate Change: A Multidimensional Global Threat}

Climate change is a phenomenon that reflects multiple and multifaceted variations in climatic characteristics. It is largely linked to human overexploitation of the planetary resources responsible for greenhouse gas emissions (IPCC, 2007; Gemenne, 2009; Ethemcan, 2016). According to data from the World Bank (2010b), climate change is everywhere in the world, especially in developing countries. Indeed, the African continent and particularly the Sahel is one of the most exposed regions in the world and the most affected by climate impacts due to various levels of vulnerability. For Afifi (2011), in Niger these changes are reflected, among other things, by more frequent and greater flooding, extreme weather conditions, desertification, land degradation, the shrinking of Lake Chad, the problems of Niger river, deforestation and the advancement of sand dunes. These climatic manifestations ultimately affect water availability, food security and the scarcity of the most essential livelihoods of already vulnerable populations. All of Niger is therefore subject to these different climatic manifestations which represent the mechanisms by which populations are forced to migrate.

\section{The relationship between climate change and migration}

The links between the environment and migration are as old as the history of mankind. Indeed, the environment has always been a factor of migration. In all parts of the world, people have had to migrate for thousands of years for environmental reasons. In addition, the climatic impacts that cause migratory flows are among others: the intensity of natural disasters, land degradation, sea level rise and the scarcity of drinking water resources, also called water stress. These types of changes have different impacts in their manifestations. Natural disasters are brutal and localized. While land degradation, advancing sand dunes, sea level rise, drought, deforestation and water stress are more progressive and affect larger areas. These different types of changes do not produce similar migrations and therefore do not require the same policy responses (Alex and Gemenne, 2016).

Indeed, it is very often compulsory to migrate (forced migration) after a natural disaster. However, the recurring manifestations of drought and similar impacts threaten food security and livelihoods, especially for people who depend on rain-fed agriculture. The

www.scirj.org

(C) 2021, Scientific Research Journal

http://dx.doi.org/10.31364/SCIRJ/v9.i05.2021.P0521857

This publication is licensed under Creative Commons Attribution CC BY. 
affected populations decide to resort to migration (voluntary migration) to adapt during bad years or bad seasons. These recurring protests deplete the resources of the affected population, including finances, seeds and livestock, reducing their ability to compensate for the effects. In other words, the more connected the episodes of drought and other similar events are, the more farmers and herders decide to migrate. In addition, the unpredictability of rainfall has also changed the situation of many households who can no longer meet their most basic survival needs. The situation worsens for them, so that they remain more likely to migrate permanently (Oxfam, 2017).

Therefore, to fully understand the impacts of climate change on migration, it is necessary to distinguish the different types of mobility that may be associated with environmental factors.

A) Short or long-term migration: These terms are used to distinguish between short-term displacement (three months to one year) and long-term migration (more than one year). While most authors now claim that environmental change primarily results in temporary migration, the media and the public tend to view this as long term. However, this typology is far from systematic: droughts have long fueled the dynamics of temporary migrations. Whereas natural disasters generate long-term migration. This underlines the importance of distinguishing between permanent migration and temporary mobility.

B) Short and long-distance migration or national and international movements: Discussions of the relationship between climate change and migration seem to have focused almost entirely on international migration. However, most of the migrations triggered by environmental factors are internal migrations (villages to cities, from one area to another).

C) Forced migration and voluntary migration: The temporality of migration is also linked to the nature of environmental processes. Slow events such as desertification, drought or sea level rise are associated with voluntary migrations, while sudden events such as large floods, tropical cyclones cause forced migrations (Etienne and al., 2010).

In other words, for Alex and Gemenne (2016), environmental migration has three dimensions: The duration (from a few days of migration to a permanent migration), the levels of preparation (from forced migration to planned migration), and finally, no migration is ever fully forced or it is certainly not voluntary. The term climate migration actually covers many migratory situations: some migrations are compulsory, others voluntary, most are internal, others are international, some are short-term, others are long-term or permanent.

\section{Theoretical approaches to climate migration}

The issue of climate migration has been theorized by several researchers around the world. However, there are several contrasts or nuances that characterize this new theoretical approach to climate migration. In fact, different visions are opposed in the theoretical approach of environmental migration. Suhrke and Visentin (1991) and Morissey (2012) describe two main approaches that differ as well as the rhetorical form used to determine climate migration, the scientific purposes followed, the methodology used and the policies recommended.

A) Maximalist approach or the Alarmists: The authors behind this approach claim to have used the concept of environmental migration for the first time continue the research work of El-Hinnawi (1985). Indeed, this approach highlights a direct causal relationship between climate change and population migration. Westing (1992), Myers (1993), and Ramlogan (1996) produce neo-Malthusian approaches: global population growth and intensifying climate change dramatically reduce available resources and increase population vulnerability. Advocates of the maximalist approach take a holistic-deductive methodological

www.scirj.org

(C) 2021, Scientific Research Journal

http://dx.doi.org/10.31364/SCIRJ/v9.i05.2021.P0521857

This publication is licensed under Creative Commons Attribution CC BY. 
approach (Castles, 2002) and use the controversial term "refugee" to present people displaced by the effects of climate change. However, this vision does not always respond to an adaptive strategy (Hunter, 2005).

B) Minimalist approach or the Skeptics: The second vision brings together researchers who think everything has been amplified and exaggerated. This approach, led by geographer Richard Black, does not call into question the climatic factor in the migration decision (Black and al., 2011). However, the approach establishes an indirect relationship between climate change and observed migration. Indeed, for these researchers, the migrations observed in recent years are linked to socio-economic, political and / or cultural issues (Hunter, 2005). Thus, the defenders of this approach express their distrust of equating migration directly with the manifestations of climate change (Hugo, 2008, p. 112). This vision attempts to take into account the power relations that structure social relations. For the authors of minimalist approach, it seems difficult to empirically isolate the climatic factors in the decision to migrate populations: populations do not move in a linear fashion, and socio-economic, political and cultural contexts, in certain cases, are the basis or increase migration (Black and al., 2013). Indeed, it is unimaginable to separate the impact of climatic conditions from other factors of migration. Migration due to climatic hazards is complex and many other factors influence households' migration preferences.

\section{Migration: A full-fledged climate change adaptation strategy}

Migration is one of the adaptation strategies that traditionally alleviate certain painful situations due to the impacts of climate change (Gemenne and Ozer, 2014). It constitutes a strategy of adaptation to climate change as old as humanity. Environmental migration is not a new phenomenon, the environment has always been a factor in migration. Indeed, almost all the great migrations known to mankind are caused by environmental or climatic changes. For example, the Lisbon earthquake in 1755 caused huge flows of migrations of people seeking refuge in Portugal and Europe. While this link is not new, it has gained high visibility over the past three decades through awareness of current climate change issues (Oxfam, 2017).

For Amélie (2018), migration has always been an important mechanism for adapting to climatic constraints. Rural societies, of course, acted in concert with their animals, trying to maintain their nomadic habits by moving from puddle to pasture to escape drought. In western Sudan, for example, studies have shown that one of the ways families cope with drought is to send a family member (male) to Khartoum to find paid work to support themselves, their needs until the end of the drought. Strong studies on the link between climate change and migration (Henry and al., 2003; Jonsson, 2010; Afifi, 2011) and the fact that migration can be a strategy of adaptation to climate risk (Mcleman and Smit, 2006; IOM, 2008; Merve, 2018) were conducted.

According to Gemenne (2016), the relationship between migration and adaptation to climate change is threefold: it concerns both regions of origin, regions of destination and migration itself. In addition to reducing our greenhouse gas emissions, the development of adaptation strategies in the regions of departure will be the only way to limit the size of migratory flows. In some cases, migration will be the ultimate option that will only be considered when various coping strategies fail. Moreover, as noted above, migration itself, rather than representing an adaptation failure, can in some cases be developed as a full-fledged adaptation strategy. In this case, the choice of migration will be a strategy that will allow migrants to reduce their vulnerability to the effects of change (Alex and Gemenne, 2016).

\section{Method}

For the purposes of this article, the qualitative research method was used. Indeed, for some time, research in the social sciences has turned to qualitative research that allows to examine and understand in depth the events and phenomena of the human environment (Yıldırım and Şimşek, 2013). In addition, under the qualitative research method, data is not collected as numerical values, qualitative 
data is obtained from in-depth interviews and then subjected to analysis (Akbaş, 2010). Therefore, in the context of this work the emphasis is on the socio-anthropological approach through in-depth semi-structured interviews, observations and analysis of documents to better understand the theme. The complexity of the issues of the effects of climate change on migrants makes it almost compulsory to use a qualitative approach to analyze in depth the discourses of climate migrants and all the other key players linked to the research theme.

\section{Target group}

As part of this research, 49 in-depth semi-structured interviews were conducted with the target group. The target group is made up of climate migrants, farmers, breeders, administrative and customary authorities, researchers, members of associations and NGOs, traditional leaders, local elected officials, climate change and migration experts and technicians ... The questions asked are developed according to the categories of the target group. These questions are also addressed according to the knowledge of the interviewee on the research topic. Thus, a total of forty (49) people, including eight women (8) and forty-one men (41), supposed to represent the people concerned by the study were interviewed on the basis of a semi-structured interview technique. During the interviews, the interviewees were informed that their names would remain confidential (anonymity) within the framework of this study in order to create a more comfortable conversation environment, taking into account the cultural, temporal, socio-political situation of the country. In this sense, abbreviations are used to describe the participants. Therefore, the letter F represents women and the letter $\mathrm{M}$ represents men. Thus, each letter is accompanied by a number indicating the number in the order of the interview (Examples: M1, M2, M3 ... or F1, F2, F3).

\section{Sample}

For this study, respondents were selected on the basis of a non-probability sampling method. Because the participants must have professional experience and / or be an important actor on issues related to climate change and / or migration and all related issues. The most appropriate sampling method in this research is therefore random. Because the research questions are based on a random selection of all the actors involved. The basic assumption is that the units characterizing the study population are chosen at random. Additionally, snowball sampling has been used to help identify potential participants with similar characteristics to increase the number of participants (Blumberg, Cooper and Schindler, 2008). The objective set through this second sampling method is to meet participants who are familiar with the research subject.

\section{Application}

This research is based on a qualitative research method through in-depth semi-structured interviews. Indeed, the effects of climate change on migration in Niger cannot be fully understood without an in-depth discussion with the population concerned, i.e. the people who are actually experiencing the situation of climate change and migration. As part of this research, although the interview guidelines developed consist of open-ended questions, other alternative questions are added as needed during the interview. The personal experiences of participants are used to gather the most in-depth information possible. Thus, thanks to this interview method, which offers flexibility in conducting the interview, it is easier and more likely to obtain the desired information.

These interviews took place in different places such as camps for refugees or displaced persons, ministries, universities, houses, headquarters of associations and NGOs, fields, gardens, streets, offices. Thus, in this study, the shortest interview lasted 29 minutes and the longest interview lasted 1 hour 38 minutes. Some of these interviews were recorded directly with the consent of the participants, as

www.sciri.org

(C) 2021, Scientific Research Journal

http://dx.doi.org/10.31364/SCIRJ/v9.i05.2021.P0521857

This publication is licensed under Creative Commons Attribution CC BY. 
the recording offers important opportunities to fully understand and analyze the data collected. The interviews were recorded using a tape recorder and then transcribed according to the original. However, it should be noted that some of the participants categorically refused to record their voices, despite our multiple explanations. For these particular cases, the interviews were therefore marked on the basis of the note taking.

\section{Data Analysis}

This step explains the process of analyzing the data recorded using a tape recorder and taking notes. The opinions expressed by interview participants were written sequentially according to the original and were subjected to content analysis after being proofread repeatedly. This is one of the exclusive means of this form of analysis, which consists of coding the different interviews and coding the responses in the different categories. This approach allows responses to be measured and avoids over-emphasizing the opinions expressed by a minority of respondents and therefore unimportant. It also helps reveal facts that may be hidden in the data and identify concepts and themes that can only be recognized with a descriptive approach. To make the analysis clearer and simpler, the data is encoded by naming meaningful parts such as words, sentences, themes or paragraphs.

Then comes the actual coding phase, which consists of dividing the data into units of analysis, defining the categories to accommodate them, and then placing the units in these categories (Grawitz, 1996). Thus, similar aspects between these codes were examined and themes likely to group them under certain categories and to explain the data at a basic level were reached. Finally, some of the research results were reported and interpreted on the basis of these codes and themes. In this section, direct quotes from participants' responses are added to reflect the interviews as they are.

\section{Findings}

In Niger agriculture and livestock are the main activities of the population. However, the climate crises that hit the Sahel do not spare this country. The degradation of agricultural and pastoral lands, the decrease and poor distribution of rainfall, have led to the decrease in agricultural and pastoral production. Thus, indisputable links between climatic manifestations and the quality of agro-pastoral production are perceptible. These close relationships observed by the populations push them to develop several adaptation strategies. Among these strategies developed in Niger, migration occupies a preponderant place.

However, in Niger migration due to the effects of climate change traditionally takes place from villages to urban centers and from the most desert areas to areas where the land is still fertile. The migration from the villages to the big cities is peculiar to the farmers who after the field work leave the villages to spend the rest of the year in the city in search of a better situation (well-being). This climatic migration from villages to cities constitutes a refuge (adaptation) for rural populations who seek to fill the gaps caused by the effects of climate change. The migration of pastoralists depends on the fertility of the areas. The most fertile areas are made up of the southern regions of the country, in particular the regions of Dosso, Maradi, part of the Zinder region and the city of Niamey as the capital and place of concentrations of administrations and services. These regions benefit from migratory movements from the regions of Agadez, Tahoua, Diffa and Tillabéri. The northern regions are essentially breeding areas par excellence of the country and a large part of the population is nomadic. Nomads migrate according to the seasons, water, grasses and other needs of their animals.

This climatic migration from villages to cities and from areas most affected by climatic hazards to more fertile areas constitutes an appropriate response to the effects of climate change, as evidenced by this extract from an interview conducted with a farmer:

www.sciri.org

(C) 2021, Scientific Research Journal

http://dx.doi.org/10.31364/SCIRJ/v9.i05.2021.P0521857

This publication is licensed under Creative Commons Attribution CC BY. 
A few years ago, the farmer and herder had everything and no one else even accidentally envisioned leaving their village for the city because the crops were good and plentiful. No pastoralist also left his pastoral zone because he had almost everything for their cattle. But now no one can continue to live in villages or desert areas during periods of welds, migration is an alternative considered to fill the deficits created by climatic hazards. (Interview with M12, farmer and member of the Niger Farmers Association).

In a context of food crises, migration therefore appears to be a strategy developed within the family framework and often even at the village level. This form of adaptation strategy to climate change has already been described by the Franco-Nigerian researcher Olivier de Sardan (2008, p. 228) who shows that some families decide during the period of food crises to send some of their members especially the youngest in migration. This migration due to climatic consequences represents a strategy for adapting to climate change and reducing the economic vulnerability of households. Often this adaptation strategy mobilizes all the men of the village:

In recent years, after the harvests, all the men in the village are migrating, leaving the women, children and the elderly. This mass migration reveals the extent of the vulnerability of the populations and the consequences of climate change on agropastoral productions which constitute the main activities of the population (interview conducted with M6 traditional chief)

Migration as a strategy for adaptation to climate change also plays a key role in transforming social dynamics across the country. Indeed, the population of Niger lives in a form of social and even legal organization in which the man has family authority. The traditional role of women is to take care of household chores and childcare. However, the departure of men for migration delegates a particular responsibility to women and pushes them to leave the traditional sphere in which they had remained during all this time. So, thanks to this form of new freedom due to the absence of the husband and the transfer of funds by the latter, some women invite themselves on a stage formerly reserved only for men.

For some time now, apart from their traditional activities, women have been involved, like men, in the practice of several activities of small businesses, weaving, market gardening, processing of agro-pastoral products. These small activities practiced by women reduce their vulnerability and improve household income (Interview conducted with F8, researcher and migration specialist)

This fully-fledged climate change adaptation strategy ensures the development of several functions. The main function of this adaptation strategy is the mobilization of additional resources to fill the gaps in agricultural and pastoral production due to climatic hazards. The families remaining in the village receive support through the transfer of funds from these migrants:

Climate migrants come to the aid of their families even if, moreover, this support is very often insufficient to meet the real needs of the family. However, even if the transferred fund generally makes it possible to pay just food, it still improves the quality of life of certain households by allowing them to reduce their vulnerability resulting from the impacts of climate change. However, certain equally important needs such as health costs, the cost of schooling for children, clothing, etc., remain unresolved (Interview conducted with F5, a wife of a migrant).

However, despite the role played by the transfer of funds from migrants in the context of adaptation to climate change, some authors believe that the transfer of funds develops the spirit of dependence on climate migration and laziness of the population and pushes them further into the vulnerability.

www.sciri.org

(C) 2021, Scientific Research Journal

http://dx.doi.org/10.31364/SCIRJ/v9.i05.2021.P0521857

This publication is licensed under Creative Commons Attribution CC BY. 
Climate migration also ensures the development of significant social capital (for migrants). During their stays, climate migrants strengthen their social capital by learning new professions that they will practice on their return. This adaptation strategy also ensures the development of the creative spirit and self-independence of migrants through the development of income-generating activities. Climate migration also playing an important role in the context of technology transfer at the local level:

Return migrants have always been models for other young people. The first radios and televisions of the village were brought by the migrants. Now even more, because you can find here all those which one finds in the industrialized countries and the big cities of the world. This equally important contribution is to be put to the credit of migrants (Interview conducted with M1, returning migrant and regional coordinator of the association of former migrants).

As part of their migratory stay, climatic migrants also undergo a very significant change in their socio-professional living conditions. Climate migrants are traditionally farmers or herders, in fact they are severely affected by climatic hazards. Thus, climate migrants are very often forced to reconvert in other survival activities. These survival activities allow migrants to help the family, secure the herds for pastoralists and at the same time save to buy animals and join the bush to try to revive themselves in pastoralism. For farmers, these activities allow them not only to come to the aid of the family but also to renew agricultural equipment and to stock up on seeds.

When the farmlands were productive and the pastoral lands were so rich, I cultivated almost everything, my older brother was also a breeder of a large herd. But now we can no longer depend on these activities. My life is divided between farming in the village and guarding in town during the dry season (Interview conducted with M37, climatic migrant).

Migration as a strategy for adapting to the impacts of climate change is fueling the development of new phenomena. Indeed, communities in Niger are traditionally made up of extended families headed by an elder who does not necessarily mean the oldest of the family but rather the most responsible. The eldest is the moral, economic responsible and represents the family wherever the need arises. However, migration as a strategy for adapting to climate impacts plays an important role in the breakdown of extended families into nuclear families. Indeed, migration allows migrants to be economically independent. This migrant's economic independence creates a feeling of revolt and allows him to escape the control of the eldest. Contrary to tradition, climate migrants generally choose their wives and have difficulty returning to the practice of traditional activities (agriculture and breeding).

It is thanks to migration that a villager becomes a city dweller and he manifests it through a categorical refusal to practice the activities of his parents and grandparents, because for many agriculture and animal husbandry are activities reserved for villagers (Interview conducted with M25, former climatic migrant)

The phenomenon of migration linked to climate change like other phenomena can be associated with innumerable socio-economic consequences. In Niger, climatic migration associated with a galloping demography, is at the base of the rapid urbanization observed in recent years. Migratory movements due to climate change play a very important role in the redistribution of the population in Niger. Indeed, the areas to which people migrate the most are urban centers and southern regions. The rural population declines strongly in favor of migration to city centers. However, this migration to large cities explains the unbridled urbanization of recent years. This rapid urbanization exceeds the pace of development of infrastructure and landscaping, which in many cases is very polluting. This passage complements the results obtained by OIM (2010) and FAOCIRAD (2012) which present climate migration as a natural blockade to the process of development of rural economies and the invasion of urban and peri-urban centers, the main distribution points of the aid, which creates a problem of co-management over existing infrastructure and natural resources (Brown, 2008).

www.scirj.org

(C) 2021, Scientific Research Journal

http://dx.doi.org/10.31364/SCIRJ/v9.i05.2021.P0521857

This publication is licensed under Creative Commons Attribution CC BY. 
Migration to cities creates the conditions for an imbalance between the rapid growth of the population and the structure of the city, which can no longer meet the basic needs of the population (Interview conducted with M30, civil society actor)

Migration is also an amplifying factor of social tensions and above all an instigator of conflicts in the reception area. In Niger, migration due to climate change causes conflicts between farmers and herders over the scarce resources they share (wells, lakes, fields, passageways for animals). Other very important problems at the origin of the conflicts in Niger are the problems or lack of feed for the livestock. These problems push herders to take their cattle to farmers' fields before the harvest is over. In addition, land reserved for breeding is sometimes occupied by farmers. The results obtained confirm those of SIPRI (2018), in which it is argued that migration resulting from climate change poses multiple security problems for people and governments. In addition, the scarcity of resources necessary for survival (water, food, feed for cattle) explains why everyone wants to obtain them at the cost of any means. However, very often this turns into identity or inter-community conflicts.

You cannot spend all your time investing in cultivating your field and one night the herders allow their animals to eat everything. The breeders are impatient by nature, they invade us every year before the end of the harvests. The clashes between us are traditional and cause dozens of deaths each year in Niger (Interview conducted with M13, Farmer).

Some migrants leave their village with the idea in mind that the city is an El Dorado. While the realities are often quite different, migrants who fail to find such dreamy jobs often engage in criminal activity, even forming gang groups. Some migrants immerse themselves in the consumption of alcohol, drugs and other dangerous products.

The environment influences man, every day that God makes the people arrested are presented to us by the night police (patrol) and they are mostly people from villages in search of work (Interview conducted with F7, actor of Justice).

The social living conditions of climate migrants very often remain difficult. Faced with exacerbated unemployment the mismatch between supply and demand for employment, the underqualification of rural labor in the urban market, migrants are major players in social instability (armed robbery, gang group and urban banditry). Public policies on the promotion of employment, vaccination campaigns, access to education and health care, become more complicated and, obviously, epidemiological waves are likely to pest in the arrival areas (Brown, 2008; IOM, 2012). Climate migration also serves as the basis for the spread of contagious and communicable diseases. The risks of exploitation of women and children, of sexual violence and of human trafficking are heightened by sudden climatic processes causing spontaneous migration.

\section{Conclusion}

In conclusion, the effects of climate change accelerate the phenomenon of land degradation which leads to many upheavals. Indeed, Niger is one of the most dependent countries on agriculture and livestock in the world. Agriculture and livestock are also highly dependent on climatic conditions. Since around $85 \%$ of Niger's population is employed in rain-fed agriculture and herding, it is easier to understand the potential devastating effects of climate change on the country. The frequency of extreme events such as drought, high temperatures, floods, winds and irregular rains has been increasing for several decades.

Faced with all these situations, the populations find themselves obliged to create the conditions for favorable adaptation to climate change, which is a sine qua non for their survival. Developments in adaptation strategies at the national and local levels have therefore become more than necessary in order to cope with the impacts of climate change. Among these strategies, climate migration occupies

www.sciri.org

(C) 2021, Scientific Research Journal

http://dx.doi.org/10.31364/SCIRJ/v9.i05.2021.P0521857

This publication is licensed under Creative Commons Attribution CC BY. 
a prominent place. In this country, climate migration is one of the biggest strategies that offers prospects for adaptation to climate change.

Therefore, this study was conducted to deeply analyze the point of view of local populations on the place or role of migration in the context of adaptation to the effects of climate change. For this article, the qualitative research method was used. In this perspective, indepth interviews were conducted with resource persons and non-governmental organizations representing the local population.

As a result, it emerges that climate migration is done in order to mobilize additional resources to help the population withstand the effects of climate change. The financial resources and social capital capitalized during this migratory experience allow the affected populations to improve the conditions for their social and economic emancipation. Therefore, the reflex of using migration as the main strategy for adapting to the effects of climate change is a favorable response.

Research results also show that more and more young people are reluctant to engage in agriculture and animal husbandry. These young people prefer to migrate to the more productive areas and inner cities of the country in order to engage in gainful activities. This migration allows migrants to overcome environmental constraints directly linked to climate change and the decline in agro-pastoral production. Several interviewees claim to have adapted to climate impacts thanks to the money transfers they receive from members of their families in migration. The study also shows how climate migrants help village families when they find work. As a result of the analysis, the former migrants invest in the trade upon their return. They also return with social capital and experiences they have acquired during their stay. They also actively participate in technology transfer.

The available data shows that the vast majority of people who have to relocate prefer to travel to the nearest urban centers or border areas. Much of this is due to the lack of funds needed to travel to remote areas or leave the country. However, given demographic trends, large cities and southern regions will no longer be able to absorb migratory flows. Therefore, in the future, many people affected by the vagaries of the weather are likely to move to distant cities or neighboring countries as a lifeline.

Climate migration, despite its important role in the context of adaptation to climate effects, favors the development of social, economic, cultural and health problems. In addition, the populations of the host areas see climate migrants as a socio-economic and cultural threat. The determining factor of the economic threat is the competitive environment associated with the exploitation of scarce resources as well as the labor market. The presence of migrants with cheap labor leads to a negative view of the local population. The perceived realistic and symbolic threats are very important because of their potential to reveal certain discriminatory and exclusionary practices against climate migrants.

In short, analyzing climate migration as a strategy for adapting to climate change in Niger comes down to addressing migration in all of these facets. Because climatic problems are at the root of all the difficulties facing populations. Solving these big problems is the main challenge in building a prosperous and vibrant Nigerien society. In this context, the above and the only central, fundamental value that allows populations to cope with climate effects remains climate migration.

\section{References}

Afifi, T. (2011). Economic or environmental migration? The push factors in Niger.

International.

www.scirj.org

(C) 2021, Scientific Research Journal

http://dx.doi.org/10.31364/SCIRJ/v9.i05.2021.P0521857

This publication is licensed under Creative Commons Attribution CC BY. 
Banque Mondiale. (2010b). Rapport sur le développement dans le monde Développement et changement climatique

Black, R., and al. (2006). Migration and development in Africa: an overview migration and development series Southern African Migration Project, Cape Town

Black, R., and al. (2011b). Migration as adaptation Nature 478 447-9

Black, R., and al. (201a). Migration, immobility and displacement outcomes following extreme events Environmental Science and Policy27 s32

Brown, O. (2008). Migration and climate change IOM Research Series IOM, Geneva

CNEDD. (2013a). Rapport I : Evaluation des besoins en technologies d'Adaptation aux Changements Climatiques pour les secteurs de l'Agriculture et des Ressources en Eau

Cooper, D., \& Schindler, P. (2008). Business research methods (10th ed.). New York, McGraw-Hill/Irwin.

Ethemcan, T. (2016). Kim giden, kim kalan? COP21 sonrası iklim değişikliği ve göç.

Gemenne, F. (2009). Géopolitiques du changement climatique, Paris, Armand Colin.

Gemenne, F. and Blocher, J. (2016). How can migration support adaptation? Different options to test the migration-adaptation nexus Migration, Environment and Climate Change: Working Paper Series1/2016 IOM, Geneva

Gemenne, F., et Ozer, P. (2014). Afrique : Le péril des migrations climatiques. Rossel \& Cie. Bruxelles/Belgique. 1375-5668.

GIEC. (2007). Bilan 2007 des changements climatiques. Contribution des Groupes de travail I, II et III au quatrième Rapport d'évaluation du Groupe d'experts intergouvernemental sur l'évolution du climat [Équipe de rédaction principale, PACHAURI, R.K. et REISINGER, A. (publié sous la direction de)]. GIEC, Genève, Suisse.

Grawitz, M. (1996). Méthodes des sciences sociales, Paris, Dalloz, Coll. « Précis Droit public. Science politique »

Henry, S, B, P., and Lambin, E, F. (2003). Modelling the influence of the natural environment on inter-provincial migration in Burkina Faso, West Africa Applied Geography23 115-36.

Jonsson, G. (2010). The environmental factor in migration dynamics-a review of African case studies International Migration Institute Working Papers No. 21, Oxford.

Merve, S. Ilık Bilben. (2018). Antropojenik İklim Değişikliği Bağlamında Göç Tartışmaları.

Morrissey, J. (2012). Rethinking the 'debate on environmental refugees': from 'maximalists and minimalists' to 'proponents and critics' Journal of Political Ecology19 36-49

OIM. (2008). Migration de retour : défis et opportunités, Note Dialogue international sur les Migrations de 2008.

OIM. (2009). Les migrations au Niger : état des lieux, enjeux et perspectives, Document thématique préparé pour l'OIM par Mounkaila Harouna.

OIM. (2013). Formation des membres de l'ONG LMCTE en matière de lutte contre la traite.

www.scirj.org

(C) 2021, Scientific Research Journal

http://dx.doi.org/10.31364/SCIRJ/v9.i05.2021.P0521857

This publication is licensed under Creative Commons Attribution CC BY. 
OIM. 2(007). Glossaire de la migration, Droit à la migration n9, Genève.

Olivier de Sardan, J.-P. (sous la dir.).(2008). La crise alimentaire de 2004-2005 au Niger, Revue Afrique contemporaine $n^{\circ} 225$.

Piguet, E. (2010). Linking climate change, environmental degradation and migration: a methodological overview Wiley Interdisciplinary Reviews Climate Change1 517-24

Programme Pilote Pour la Résilience Climatique. (2010). Aide-mémoire mission conjointe du PPCR-Niger, Niamey. 